\title{
In vitro research of anti-HSV-1 activity in different extracts from Pacific oysters Crassostrea gigas
}

\author{
Cécile Olicard ${ }^{1,2,3}$, Yohann Didier ${ }^{2}$, Christel Marty $^{1}$, Nathalie Bourgougnon ${ }^{1}$, \\ Tristan Renault ${ }^{2, *}$ \\ ${ }^{1}$ Laboratoire de Biotechnologie et Chimie Marines, EA 2594, Université de Bretagne Sud, Campus de Tohannic, \\ Centre de recherche Yves Coppens, 56017 Vannes, France \\ ${ }^{2}$ IFREMER, Laboratoire de Génétique et Pathologie, 17390 La Tremblade, France \\ ${ }^{3}$ Laboratoire de Biologie et Environnement Marins, Université de La Rochelle, 17042 La Rochelle, France
}

\begin{abstract}
Mortalities related to the detection of Ostreid Herpesvirus 1 (OsHV-1) have been previously reported in France among larvae and spat of the Pacific oyster Crassostrea gigas. Adult oysters appear less sensitive to herpesvirus infections, although OsHV-1 has been detected in adults without signs of disease or mortality. This suggests that the virus is able to persist in its host and that adult oysters may be able to control OsHV-1 infection. Little is known about antiviral substances in invertebrates. The present work concerns the research of antiviral substances in adult oyster C. gigas, where putative antiviral activities were monitored using 3 strategies: (1) in metabolites with variable polarity, (2) in peptidic extracts and (3) in crude haemolymph. In vitro antiviral assays were based on inhibition of Herpes simplex virus type 1 (HSV-1) replication in Vero cell monolayers. All extracts presented no cytotoxicity. Antiviral activity was detected in the fresh filtered haemolymph $\left(\mathrm{EC}_{50}: 425 \mu \mathrm{g} \mathrm{ml}^{-1}\right)$ and seasonal variation of the haemolymph antiviral activity was monitored.
\end{abstract}

KEY WORDS: Oyster · Crassostrea gigas · Antiviral defence $\cdot$ OsHV-1 $\cdot$ HSV-1 $\cdot$ Antiviral peptides · Haemolymph

\section{INTRODUCTION}

Shellfish are being increasingly cultured around the world and represent an important economic activity sustained by private and public enterprises. The increase in aquaculture production has been made possible by the accumulation of knowledge and advances in technology which have led to intensive production of bivalve larvae and seed. Although new rearing techniques can improve and expand production, they also raise a number of issues. Animal transfers at national and international levels have increased dramatically in recent decades. Such procedures favour the emergence and dissemination of infectious diseases, which represent a major limiting factor in shellfish production.

Mortalities have been reported in different bivalve species and associated with the presence of viruses belonging to various families (Renault et al. 1994a, Arzul et al. 2001). The first description of a virus related to the Herpesviridae was reported in adult eastern oysters Crassostrea virginica (Farley et al. 1972). Since 1991, high mortalities of oyster larvae and juveniles have been observed regularly around the world in association with herpesvirus infections in Pacific oyster C. gigas (Hine et al. 1992, Renault et al. 1994a,b), European flat oyster, Ostrea edulis (Comps \& Cochennec 1993, Renault et al. 2000) and Tiostrea chilensis (Hine et al. 1998). Like other herpesviruses, the Ostreid Herpesvirus (OsHV-1) infecting C. gigas seems to occur at high prevalence in healthy adult oysters in France (Arzul et al. 2002). The DNA and viral proteins of OsHV-1 have been detected in asymptomatic adult oysters. The adult oysters may thus play the role of virus carriers and reservoirs, promoting transmission to larvae and juveniles, as previously 
reported (Le Deuff et al. 1996). Adult oysters could be more resistant to viral infections in developing effective immunity against OsHV-1.

Despite the impact that viral diseases have on shellfish cultures, little is known about how shellfish farmers can prevent and treat viral infections or about how shellfish control viral diseases. Although invertebrates do not produce specific antibodies (Shapiro 1975), they may rely on their innate defence for host protection against viruses. Reports on viruses infecting bivalves are available today, but those focusing on antiviral defence mechanisms are poorly documented. Antiviral substances have rarely been reported in bivalves and are particularly rare for Crassostrea gigas (Prescott et al. 1966, Li \& Traxler 1972, Bachère et al. 1989, Lee \& Maruyama 1998).

The main objective of the present study was the detection of antiviral substances in adult Crassostrea gigas oysters. Antiviral and cytotoxicity activities of oyster aqueous and alcoholic extracts were evaluated in vitro against Herpes simplex virus type 1 (HSV-1) infecting Vero cells. Cytotoxicity activity assays were performed in order to demonstrate that oyster extracts were not causing Vero cell mortality. The protocol used in the present study to prepare aqueous and alcoholic oyster extracts was previously developed for extraction of marine bioactive substances (Hellio et al. 2000). Antiviral activity of oyster peptide extracts and crude haemolymph was also monitored. Peptide extraction from oyster tissues was developed on the basis of previous works on peptidic antimicrobial substances from frogs (Amiche et al. 2000, Matutte et al. 2000), lobsters (Nousiainen et al. 1998), and mussels (Mitta et al. 2000).

\section{MATERIALS AND METHODS}

Oysters. We obtained 3 yr old Pacific oysters Crassostrea gigas from shellfish farms located in the Marennes-Olèron Bassin (Charente Maritime) on the French Atlantic coast. Oysters were collected during winter and summer of 2000, 2001 and 2002. Half of the specimens were killed immediately upon arrival at the laboratory. The other half were maintained for $1 \mathrm{wk}$ in filtered seawater at $15^{\circ} \mathrm{C}$ with continuous oxygenation and starvation in order to investigate the origin of putative antiviral activities.

Tissue and haemolymph collection. To minimize inter-individual variability, 30 oysters were pooled for each experiment. Oyster haemolymph was collected with a sterile syringe ( $1 \mathrm{ml}, 23 \mathrm{G}, \mathrm{no} .16$, Terumo) from the pericardial cavity and pooled. Oysters were then sagittaly sectioned. One half was directly lyophilized and constituted the 'whole animal' sample. The other half was subjected to tissue and organ dissection (heart, labial palps, gills and mantle) and 30 similar tissues or organs were pooled and lyophilized. All samples were stored at $-80^{\circ} \mathrm{C}$.

Peptide extraction from tissues and crude haemolymph. Lyophilized tissues were homogenized in ethanol/chlorhydric acid $0.7 \mathrm{M} \quad(\mathrm{HCl}) \quad(3: 1, \quad \mathrm{v} / \mathrm{v}$; $\left.10 \mathrm{ml} \mathrm{g}^{-1}\right)$ and were centrifuged $(1000 \times g, 60 \mathrm{~min}$, $4^{\circ} \mathrm{C}$ ). Ethanol was then removed under reduced pressure (Büchi, rotavapor R124). The extracts were loaded onto solid phase extraction Sep-pack C-18 cartridges (SPE $6 \mathrm{ml}, 1000 \mathrm{mg}$, Macherey Nagel) equilibrated with acetonitril/water/trifluoroacetic acid (ACN/ water/TFA, 80:20:0.1). After washes in acidified water $(\mathrm{HCl} 0.7 \mathrm{M})$, bound material was eluted with ACN/

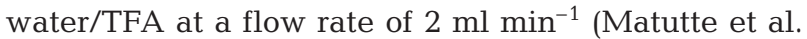
2000). Haemolymph was extracted by homogenizing in $0.1 \%$ TFA $(\mathrm{v} / \mathrm{v})$ for $1 \mathrm{~h}$ at $0^{\circ} \mathrm{C}$ and centrifugation $\left(1000 \times g, 60 \mathrm{~min}, 4^{\circ} \mathrm{C}\right)$. Extracts were loaded onto Seppack C-18 cartridges at a flow rate of $2 \mathrm{ml} \mathrm{min}^{-1}$. Bound material was eluted with a gradient of acetonitril (10, 50 and $80 \%$ of ACN) (Roch et al. 1996, Fleury et al. 1998). All fractions were lyophilized, reconstituted in double-distilled water and tested for antiviral activity as described below. Determination of total proteins in extracts was carried out by the Lowry method (Lowry et al. 1951).

Aqueous and alcohol extractions. Oysters were suspended by stirring in distilled water $\left(50 \mathrm{~g} \mathrm{l}^{-1}\right.$ of dried weight) with an ultra-turrax for $2 \mathrm{~h}$ at $4^{\circ} \mathrm{C}$. After centrifugation $\left(1 \mathrm{~h}, 12000 \times g, 4^{\circ} \mathrm{C}\right)$, the supernatant was lyophilized and constituted the aqueous extract (A extract).

To prepare alcohol extracts, oyster samples were suspended by stirring in $95^{\circ} \mathrm{C}$ ethanol $(50 \times g$ in $300 \mathrm{ml}$ ) with an ultra-turrax for $30 \mathrm{~min}$ at $4^{\circ} \mathrm{C}$. After centrifugation $\left(1 \mathrm{~h}, 12000 \times g, 4^{\circ} \mathrm{C}\right)$, the pellet was re-extracted 5 times. Alcoholic extracts were pooled and evaporated under vacuum at low temperature $\left(<-40^{\circ} \mathrm{C}\right)$. Distilled water $(100 \mathrm{ml})$ was then added and partitioned with methylene chloride $(4 \times 100 \mathrm{ml})$. Aqueous phases were collected, lyophilized, re-suspended in absolute ethanol $(100 \mathrm{ml})$, filtered and concentrated under vacuum at $4^{\circ} \mathrm{C}$ (B extract). Organic phases were collected, dried for $24 \mathrm{~h}$ under $\mathrm{Na}_{2} \mathrm{SO}_{4}$, filtered and concentrated under vacuum at low temperature $(\mathrm{C}$ extract). Extracts $\mathrm{A}, \mathrm{B}$ and $\mathrm{C}$ constituted metabolites with variable polarity. Extracts were stored at $-80^{\circ} \mathrm{C}$ before analysis (Hellio et al. 2000).

Crude oyster haemolymph. The crude haemolymph (Fraction I) was prepared from the freshly collected haemolymph and was centrifuged $\left(100 \times g, 2 \mathrm{~min}, 4^{\circ} \mathrm{C}\right)$ to remove shell debris. To obtain an acellular fraction, the haemolymph was centrifuged first at $200 \times g$ for $10 \mathrm{~min}$ at $4^{\circ} \mathrm{C}$. The supernatant was recovered and centrifuged again $\left(3000 \times g, 10 \mathrm{~min}, 4^{\circ} \mathrm{C}\right)$ and the resulting 
supernatant corresponded to fraction II. Another acellular fraction (III) was obtained by filtering the crude haemolymph through a $0.22 \mu \mathrm{m}$ sterile filter. All samples were kept at $-80^{\circ} \mathrm{C}$. Total proteins in extracts were analysed by the Lowry method (Lowry et al. 1951).

Cell cultures and virus. African green monkey kidney cells (Vero, ATCC CCL-81) were grown in Eagle's minimal essential medium (MEM; Eurobio) supplemented with $8 \%$ foetal calf serum (FCS; Eurobio) and $1 \%$ antibiotics ( $\mathrm{PCS} ; 0000 \mathrm{IU} \mathrm{ml}^{-1}$ penicillin, $25000 \mathrm{IU}$ $\mathrm{ml}^{-1}$ colymicin, $10 \mathrm{mg} \mathrm{ml}^{-1}$ streptomycin; Sigma). Cells were cultured at $37^{\circ} \mathrm{C}$ in humidified atmosphere at $5 \%$ $\mathrm{CO}_{2}$. Herpes simplex virus type 1 (HSV-1, wild type strain 17, sensitive to acyclovir) was obtained from Prof. Ingrand (Hôpital A. Béclère, Reims, France). Virus titer was estimated from cytopathogenicity according to the Reed \& Muench (1938) dilution method and expressed as $50 \%$ infectious doses per milliliter $\left(\mathrm{ID}_{50}\right.$ $\mathrm{ml}^{-1}$ ). In order to evaluate the antiviral activity, the multiplicity of infection (MOI) is used and corresponds to the virus number per cell. The HSV-1 stock had a titer of $2 \times 10^{5.8} \mathrm{ID}_{50} \mathrm{ml}^{-1}$ and MOI was $0.001 \mathrm{ID}_{50}$ cell $^{-1}$.

Cytotoxicity assays. Extract cytotoxicity was evaluated using an EPICS XL 4 flow cytometer (Beckman Coulter ). We incubated $150 \mu \mathrm{l}$ Vero cells (350 000 cell $\mathrm{ml}^{-1}$ ) with $50 \mu \mathrm{l}$ of different extracts at different protein concentrations (25 to $1000 \mu \mathrm{g} \mathrm{ml}^{-1}$ ), for 4 and $72 \mathrm{~h}$. Then, $5 \mu \mathrm{l}$ of propidium iodide (PI, $1.0 \mathrm{mg} \mathrm{ml}^{-1}$, Interchim) was added and incubated in the dark for $30 \mathrm{~min}$ at $4^{\circ} \mathrm{C}$. Results were expressed as cell cytograms indicating size (FSC value) and complexity (SSC value). Red fluorescence (FL3) cells corresponded to dead cells. As dimethyl sulfoxide (DMSO) compound is known to be cytotoxic at room temperature, we used it as a positive control. Vero cells without treatment were used as a negative control. The cytotoxicity of each extract was analysed 3 times.

Cytotoxicity was also evaluated by cell viability. Cell suspensions $\left(3.5 \times 10^{5}\right.$ Vero cells ml $\left.{ }^{-1}\right)$ were incubated with various dilutions of oyster extracts in 96-well microplates $\left(48 \mathrm{~h}, 37^{\circ} \mathrm{C}, 5 \% \mathrm{CO}_{2}\right)$ in Eagle's MEM containing $8 \%$ FCS. Triplicate assays were performed from the same homogenates. Cells were examined daily under a phase-contrast microscope to determine the minimum concentration that induced alterations in cell morphology, including swelling, shrinkage, granularity and detachment. Cytotoxicity was tested using the neutral red dye method (McLaren et al. 1983). After shaking, optical density (OD) was measured at $540 \mathrm{~nm}$ using a spectrophotometer (SpectraCount ${ }^{\mathrm{TM}} ;$ Packard). The $50 \%$ cytotoxic concentration $\left(\mathrm{CC}_{50}\right)$ was defined as the concentration that reduced the OD of treated cells to $50 \%$ of that of untreated cells. $\mathrm{CC}_{50}$ values were expressed as the percent destruction $(\% \mathrm{D})$ : [(ODc) C $(\mathrm{ODc}) \mathrm{MOCK} /(\mathrm{ODc}) \mathrm{C}] \times 100$, where $(\mathrm{ODc}) \mathrm{C}$ and
(ODc)MOCK were the OD values of the untreated cells and treated cells, respectively (Langois et al. 1986).

Anti-HSV-1 assays by cell viability. We incubated $100 \mu \mathrm{l}$ of cell suspension $\left(3.5 \times 10^{5} \mathrm{cells} \mathrm{m}^{-1}\right)$ in Eagle's MEM containing $8 \%$ FCS with $50 \mu \mathrm{l}$ of a dilution of oyster extract in 96 well microplates $\left(48 \mathrm{~h}, 37^{\circ} \mathrm{C}, 5 \%\right.$ $\mathrm{CO}_{2}$ ). Three replicates were infected using $50 \mu \mathrm{l}$ of medium and a virus suspension at an MOI of $0.001 \mathrm{ID}_{50}$ cell $^{-1}$. After incubation, antiviral activity was evaluated by the neutral red dye method (McLaren et al. 1983). Cell and virus controls were carried out simultaneously, and 3 replicates were performed using 3 different oyster homogenates. The antiherpetic compound acyclovir (9-(2-hydroxyethoxymethyl)guanine), $25 \mathrm{mg}$ $\mathrm{ml}^{-1}$ ) was used as reference inhibitor. The $50 \%$ antiviral effective concentration $\left(\mathrm{EC}_{50}\right)$ was expressed as the concentration that achieved $50 \%$ protection of virus-infected cells from virus-induced destruction. Data were expressed as a percent protection $(\% \mathrm{P})$ by the following formula: [((ODt)virus - (ODc)virus) / $((\mathrm{ODc}) \mathrm{MOCK}-(\mathrm{ODc}) \mathrm{HSV})] \times 100(\%)$, where (ODt)virus was the OD of the test sample, (ODc)virus was the OD of the virus control (no oyster extract), and (ODc)MOCK was the OD of the mock-infected control. The ratio of (ODc)virus to (ODc)MOCK was expressed as '\% of control' (Langois et al. 1986).

\section{RESULTS}

\section{Metabolites with variable polarity}

No cytotoxicity of aqueous extracts (A) and alcohol extracts (B and $C$ ) of oysters was observed for the range of concentrations tested. After 48 and $72 \mathrm{~h}$ of infection, no anti-HSV-1 activity was reported between 25 and $2500 \mu \mathrm{g} \mathrm{ml}^{-1}$ of oyster extracts (A, B and $\mathrm{C}$ ). Moreover, no variation related to seasonal sampling and starvation was found.

\section{Peptidic extracts}

The peptide extract cytotoxicity on Vero cells was analysed by flow cytometry after $4 \mathrm{~h}$ and $72 \mathrm{~h}$ of incubation (Fig. 1). After $4 \mathrm{~h}$ of incubation, all extracts presented no cytotoxicity, exhibiting $<10 \%$ dead cells. Cytotoxicity evaluation after $72 \mathrm{~h}$ of incubation showed major cytotoxicity for gills $(63 \%)$, heart $(48 \%)$, mantle $(43 \%)$, labial palps $(43 \%)$ and peptide extracts of haemolymph eluted at 10,50 and $80 \%$ of acetonitril (50, 48 and $55 \%$, respectively). The percentage of dead cells after $72 \mathrm{~h}$ of incubation with the whole animal peptide extract was low $(14 \%)$ and was no different from the cell control $(11 \%)$. After $48 \mathrm{~h}$ incubation, no 


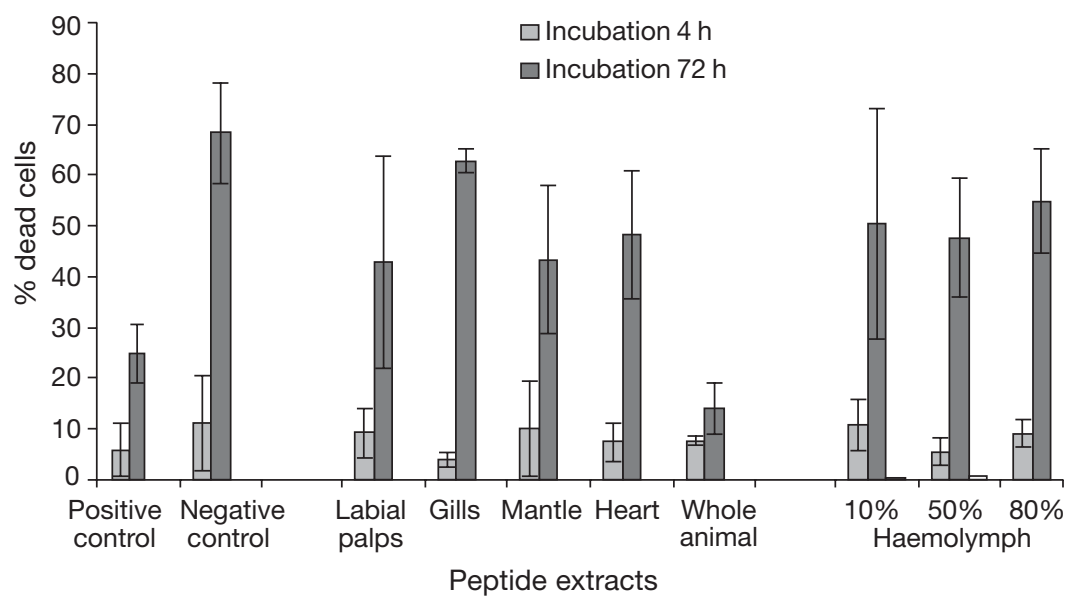

Fig. 1. Crassostrea gigas. Evaluation by flow cytometry of the winter oyster peptide extracts for cytotoxicity (\% of dead cells), after 4 and $72 \mathrm{~h}$ of Vero cells incubation. Extracts were prepared from whole oyster and dissected tissues

\section{Crude haemolymph}

Antiviral activity in crude haemolymph (I) and acellular fractions (II and III) from Crassostrea gigas exhibited a similar cytotoxicity and antiHSV-1 activity after $48 \mathrm{~h}$ incubation. No microscopically visible alteration of cell morphology was observed even at $600 \mu \mathrm{g} \mathrm{ml}^{-1}$ of total proteins. At a $600 \mu \mathrm{g} \mathrm{ml} \mathrm{m}^{-1}$ protein concentration, a $92 \%( \pm 13)$ protection of Vero cells for an MOI of $0.001 \quad \mathrm{ID}_{50} \mathrm{cell}^{-1}$ was noticed (Fig. 2). Percentages of destruction and protection were $8 \%( \pm 7)$ and $93 \%( \pm 13)$ respectively for fraction II, and $9 \%( \pm 8)$ and $87 \%( \pm 16)$ for fraction III, respectively. Acyclovir (1 $\mu \mathrm{g} \mathrm{ml}^{-1}$ ) showed a total cell promicroscopic alteration of cell morphology was observed even at a concentration of $1000 \mu \mathrm{g} \mathrm{ml}^{-1}$ of protein (Table 1) and no cell destruction occurred $\left(\mathrm{CC}_{50}>200 \mu \mathrm{g} \mathrm{ml}^{-1}\right)$. Except for the winter set of whole animal extract with an $\mathrm{EC}_{50}$ of $30 \mu \mathrm{g} \mathrm{ml}^{-1}$, no difference was observed in cytotoxic activity at different seasons or with starvation for peptide extracts.

Evaluation of anti-HSV-1 activity showed no cellular protection from different extracts for an MOI of $0.001 \mathrm{ID}_{50}$ cell $^{-1}$ (Table 1). However, a low anti-HSV-1 activity $\left(\mathrm{EC}_{50}\right.$ of $\left.50 \mu \mathrm{g} \mathrm{ml}^{-1}\right)$ was reported in peptide extracts from the whole animal only, with a visible cytopathic effect at a total protein concentration of $1000 \mu \mathrm{g}$ $\mathrm{ml}^{-1}$ (Table 1). The antiviral activity was only observed for the winter set, with or without starvation. With the specific peptide extraction protocol used, none of the other tissue extracts nor the haemolymph peptide extracts showed any anti-HSV-1 activity. No difference was observed between starved and unstarved oysters.

Table 1. Crassostrea gigas. Anti-HSV-1 activity $\left(\mathrm{EC}_{50} ; \mathrm{ll}^{-1}\right)$ and cytotoxicity $\left(\mathrm{CC}_{50} ; \mathrm{ul}^{-1}\right)$ of peptidic extracts from tissue and crude haemolymph. -: no antiviral activity; S: starvation; NS: no starvation; NC: no cytotoxicity; Hm: haemolymph; $\mathrm{Hm} 10 \%$ : extraction with $10 \%$ of acetonitrili $\mathrm{Hm} 50 \%$ : extraction with $50 \%$ of acetonitril; $\mathrm{Hm} 80 \%$ : extraction with $80 \%$ of acetonitril

\begin{tabular}{|c|c|c|c|c|c|c|c|c|}
\hline \multirow{2}{*}{$\begin{array}{l}\text { Extracts } \\
\text { Whole animal }\end{array}$} & \multicolumn{2}{|c|}{$\begin{array}{l}\text { Winter/S } \\
\mathrm{EC}_{50} \mathrm{CC}_{50}\end{array}$} & \multicolumn{2}{|c|}{$\begin{array}{l}\text { Winter/NS } \\
\mathrm{EC}_{50} \mathrm{CC}_{50}\end{array}$} & \multicolumn{2}{|c|}{$\begin{array}{l}\text { Summer/S } \\
\mathrm{EC}_{50} \mathrm{CC}_{50}\end{array}$} & \multicolumn{2}{|c|}{$\begin{array}{c}\text { Summer/NS } \\
\mathrm{EC}_{50} \quad \mathrm{CC}_{50}\end{array}$} \\
\hline & 50 & 30 & 50 & 30 & - & $\mathrm{NC}$ & - & $\mathrm{NC}$ \\
\hline Heart & - & $\mathrm{NC}$ & - & $\mathrm{NC}$ & - & $\mathrm{NC}$ & - & NC \\
\hline Mantle & - & $\mathrm{NC}$ & - & $\mathrm{NC}$ & - & $\mathrm{NC}$ & - & $\mathrm{NC}$ \\
\hline Gills & - & $\mathrm{NC}$ & - & $\mathrm{NC}$ & - & $\mathrm{NC}$ & - & $\mathrm{NC}$ \\
\hline Labial palps & - & $\mathrm{NC}$ & - & $\mathrm{NC}$ & - & $\mathrm{NC}$ & - & $\mathrm{NC}$ \\
\hline $\mathrm{Hm} 10 \%$ & - & $\mathrm{NC}$ & - & $\mathrm{NC}$ & - & $\mathrm{NC}$ & - & $\mathrm{NC}$ \\
\hline $\mathrm{Hm} 50 \%$ & - & $\mathrm{NC}$ & - & $\mathrm{NC}$ & - & $\mathrm{NC}$ & - & $\mathrm{NC}$ \\
\hline $\mathrm{Hm} 80 \%$ & - & $\mathrm{NC}$ & - & $\mathrm{NC}$ & - & $\mathrm{NC}$ & - & $\mathrm{NC}$ \\
\hline Acyclovir & 0.80 & $\mathrm{NC}$ & 0.80 & $\mathrm{NC}$ & 0.80 & $\mathrm{NC}$ & 0.80 & NC \\
\hline
\end{tabular}

tection $(100 \%)$ against HSV-1 with a low percentage of cell destruction (5\%).

\section{Seasonal variation of anti-HSV-1 activity in filtered haemolymph}

Filtered haemolymph (III) cytotoxicity and anti-HSV1 activity analysed from oysters collected over 1 yr (August 2002 to August 2003) (Fig. 3) was stable throughout the year (20\% of destruction). High antiviral activity (90 to $100 \%$ of protection) was found from August 2002 to December 2002 and in August 2003. A decrease in antiviral activity was recorded from December 2002 to May 2003. Vero cells were protected against HSV-1 infection by filtered haemolymph collected during the summer/ autumn period (Fig. 3).

\section{DISCUSSION}

A mammalian fibroblastic cell line (Vero cells) susceptible to infection by HSV-1 was selected to investigate the presence of putative antiviral molecules in Pacific oysters. Like most of the studies that have evaluated antiviral activity in aquatic invertebrates, the cell culture model is a heterologous model (Prescott et al. 1966, Li \& Traxler 1972, Azumi et al. 1990, Tamamura et al. 1993, Lee \& Maruyama 1998). No homologous viral model is available for OsHV-1 because of the lack of an oyster cell line, and OsHV-1 replication has failed in insect, fish and mam- 


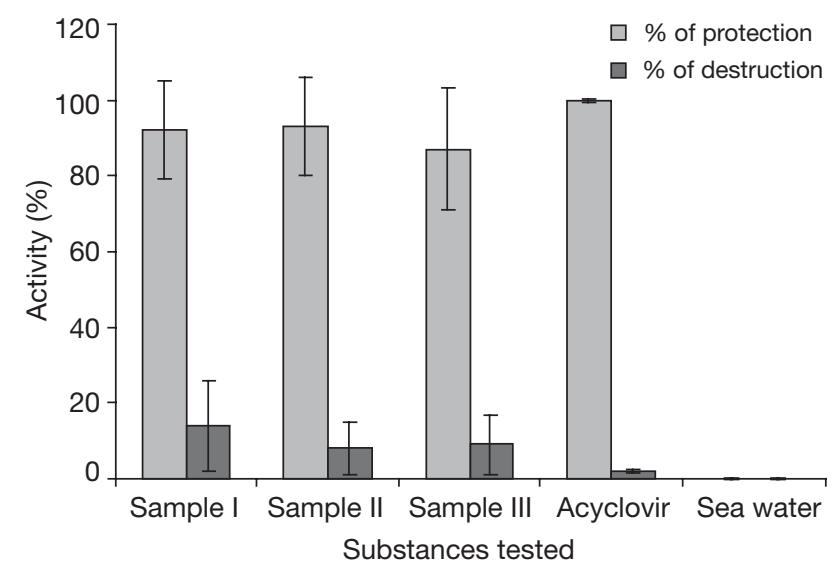

Fig. 2. Crassostrea gigas. Cytotoxicity and antiviral activity in whole haemolymph and in acellular fractions of haemolymph after $48 \mathrm{~h}$ incubation in Vero cells infected by HSV-1

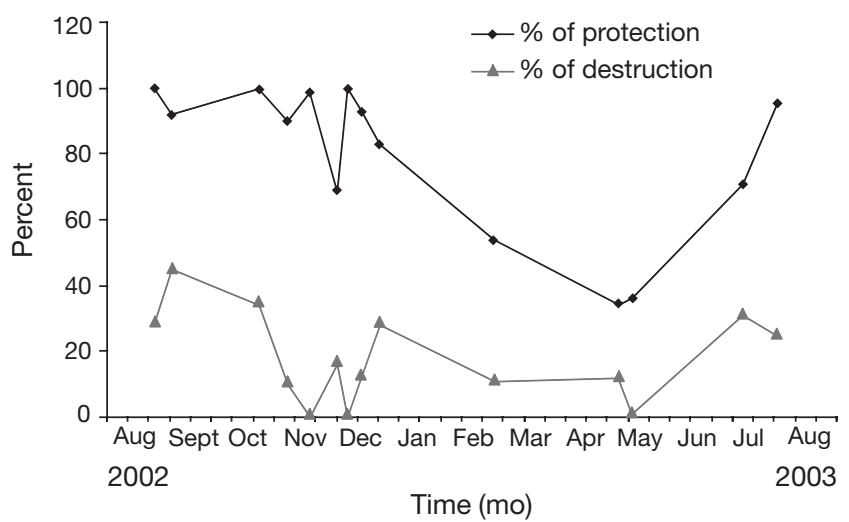

Fig. 3. Crassostrea gigas. Protection and destruction (\% of total number of oysters collected from August 2002 to August 2003)

malian cell lines and primary oyster cell cultures (T. Renault unpubl. data). The Vero cell/HSV-1 model is also currently used for screening for antiviral molecules in other marine animals (Bergé et al. 1999, Yasin et al. 2000, Maier et al. 2001).

Although several molecules extracted from invertebrates have already been characterized with broad anti-microbial activity (Nakamura et al. 1988, Mitta et al. 2000, Zasloff 2002), antiviral effects have rarely been reported. Limasset et al. (1961) reported antiviral activity in extracts from mussel Mytilus edulis, clam Mercenaria mercenaria, and oyster Crassostrea gigas against the Tobacco Mosaic Virus (TMV). Li \& Traxler (1972) reported antiviral activity in clam Mya arenaria aqueous extract against an amphibian virus (LT-1).

Antiviral activity was not found in this study from aqueous and alcohol extracts, despite a lack of cytotoxicity up to $1 \mathrm{~g}$ of extract.

The involvement of peptides and polypeptides in the non-specific host defence response of invertebrates has been demonstrated, and a number of them, including anti-microbial peptides, have been characterized (Cociancich et al. 1994, Roch et al. 1996, Destoumieux et al. 1997, Bulet et al. 1999, Relf et al. 1999, Mitta et al. 2000). The haemolymph peptide extraction protocol has already been used in invertebrates (Roch et al. 1996, Fleury et al. 1998). Cytotoxicity analysed by flow cytometry in this study indicated that a long contact (72 h) between cells and extracts induced high cytotoxicity, with the exception of the whole animal extract. After a $4 \mathrm{~h}$ incubation, results from different extracts showed no cytotoxicity. Cytotoxicity was considered negligible in comparison with the cell control ( $6 \%$ of dead cells). Using cell culture, after a $48 \mathrm{~h}$ incubation, all extracts appeared non-cytotoxic $\left(\mathrm{CC}_{50}>\right.$ $200 \mu \mathrm{g} \mathrm{ml}^{-1}$ ).

The effect of starvation was analysed to investigate the origin of putative antiviral activities. Food ingested by the oyster may be the source of antiviral activity, but no differences were found in this study with starvation. The influence of season in relation to oyster physiology and seasonal mortalities was also analysed. Seasonal impact of variations in different physiological molecules has been demonstrated in oysters (Avery et al. 1997, Keppler \& Ringwood 2001, Ringwood et al. 2002). Moreover, OsHV-1 infections appear to be more frequent during summer (Renault et al. 1994a). Tissue type was also explored in an attempt to isolate an antiviral molecule in a specific tissue or organ. The whole animal peptide extract was the only sample found to possess anti-HSV-1 activity $\left(\mathrm{EC}_{50}\right.$ of $\left.50 \mu \mathrm{g} \mathrm{ml} \mathrm{m}^{-1}\right)$. Antiviral activity was evident in the winter set only, and was found in whole oysters but not in selected tissues or organs. However, selected protocols (Roch et al. 1996, Fleury et al. 1998, Matutte et al. 2000) may not be appropriate for oyster samples. Both peptide protocols used ACN and TFA, chemicals that are efficient for extracting some active molecules but may also denature the structure of others. Studies on antiviral activity in crab and shrimp have used simple homogenization in a balanced salt solution (Pan et al. 2000).

The present study describes the presence of antiviral activity in adult oyster haemolymph in non-purified samples. Indeed, antiviral activity was demonstrated in the 3 different haemolymph fractions (I, II and III) at an MOI of $0.001 \mathrm{ID}_{50} \mathrm{cell}^{-1}$. Moreover, a previous study strongly suggested that broadly-specific antiviral substances are present in crustaceans (Pan et al. 2000). Filtered haemolymph collected over 1 yr showed stable cytotoxicity but seasonal variation of antiviral activity. This observation confirms the presence of an antiviral substance in adult oyster haemolymph and implies that adult oysters Crassostrea gigas could be more resistant than larvae and juveniles to infection and that this substance may contribute to oyster survival despite contin- 
uing exposure to OsHV-1. Involvement of a putative antiviral molecule in the defence mechanism against OsHV-1 could provide a better understanding of invertebrate defence systems. This research may provide important clues as to the nature of antiviral innate immunity in cultured aquatic species and help to develop new approaches for the control of viral infections.

Acknowledgements. This work was supported in part by a European Union grant (QLRT-2001-01691) and a PoitouCharentes region grant. We thank Dr. K. Way (CEFAS, head of Virology Research Unit, Weymouth, UK) for his invaluable help with the English language.

\section{LITERATURE CITED}

Amiche M, Seon AA, Wroblewski H, Nicolas P (2000) Isolation of dermatoxin from frog skin, an antibacterial peptide encoded by a novel member of the dermaseptin genes family. Eur J Biochem 267:4583-4592

Arzul I, Renault T, Lipart C (2001) Experimental herpes-like viral infections in marine bivalves: demonstration of interspecies transmission. Dis Aquat Org 46:1-6

Arzul I, Renault T, Thébault A, Gérard A (2002) Detection of oyster herpesvirus DNA and proteins in asymptomatic Crassostrea gigas adults. Virus Res 84:151-160

Avery A, DeCou D, Tall B, Faisal M (1997) Variation in levels of plasma protease inhibitors among populations of the eastern oyster (Crassostrea virginica). Dev Comp Immunol 21(2):232

Azumi K, Yoshimizu M, Suzuki S, Ezura Y, Yokosawa H (1990) Inhibitory effect of halocyamine, an antimicrobial substance from ascidian hemocytes, on the growth of fish viruses and marine bacteria. Experienta 46:1066-1068

Bachère E, Hervio D, Mialhe E, Grizel H (1989) Evidence of neutralizing activity against T3 coliphage in oyster Crassostrea gigas hemolymph. Dev Comp Immunol 14: 261-268

Bergé JP, Bourgougnon N, Alban S, Pojer F and 5 others (1999) Antiviral and anticoagulant activities of a water soluble compound extracted from marine diatom Haslea ostrearia. Planta Med 65:604-609

Bulet P, Hetru C, Dimarcq JL, Hoffmann D (1999) Antimicrobial peptides in insects; structure and function. Dev Comp Immunol 23:329-344

Cociancich S, Bulet P, Hetru C, Hoffman J (1994) Insect immunity and antibacterial proteins. Parasitol Today 10: 132-139

Comps M, Cochennec N (1993) A Herpes-like virus from the European oyster Ostrea edulis L. J Invertebr Pathol 62: 201-203

Destoumieux D, Bulet P, Rodriguez J, Bachère E (1997) The antimicrobial defense of penaeid crustaceans: characterization of a new family of antimicrobial peptides in the shrimp Penaeus vannamei. Dev Comp Immunol 21:206

Farley AC, Banfield WG, Kasnic G, Foster WS (1972) Oyster herpes-type virus. Science 178:759-760

Fleury Y, Vouille V, Beven L, Amiche M, Wroblewski H, Delfour A, Nicolas P (1998) Synthesis, antimicrobial activity and gene structure of a novel member of the dermaseptin B family. Biochim Biophys Acta 1396:228-236

Hellio C, Bourgougnon N, Le Gal Y (2000) Phenoloxidase (E.C. 1.14.18.1) from the byssus gland of Mytilus edulis:
Purification, partial characterization and application for screening products with potential antifouling activities. Biofouling 16(2-4):235-244

Hine PM, Wesney B, Hay BE (1992) Herpes viruses associated with mortalities among hatchery-reared larval Pacific oysters Crassostrea gigas. Dis Aquat Org 12:135-142

Hine PM, Wesney B, Besant P (1998) Replication of a Herpeslike virus in larvae of the flat oyster Tiostrea chilensis at ambient temperatures. Dis Aquat Org 32:161-171

Keppler C, Ringwood A (2001) Expression of P-glycoprotein in the gills of oysters, Crassostrea virginica: seasonal and pollutant related effects. Aquat Toxicol 54:195-204

Langois M, Allard JP, Nugier F, Aymard M (1986) A rapid and automated colorimetric assay for evaluating the sensitivity of Herpes simplex strains to antiviral drugs. J Biol Stand 14:201-211

Le Deuff RM, Renault T, Gérard A (1996) Effects of temperature on Herpes-like virus detection among hatcheryreared larval pacific oyster Crassostrea gigas. Dis Aquat Org 24:149-157

Lee TG, Maruyama S (1998) Isolation of HIV-1 proteaseinhibiting peptides from thermolysin hydrolysate of oyster proteins. Biochem Biophys Res Commun 253:604-608

Li MF, Traxler GS (1972) Antiviral activity of aqueous clam (Mya arenaria) extract on amphibian virus (LT-1)1,2. Can J Microbiol 18:397-402

Limasset P (1961) Observations préliminaires démontrant l'existence d'inhibiteurs du virus de la mosaïque du tabac chez des animaux aquatiques, la plupart marins. CR Acad Sci 252:3154-3156

Lowry OH, Rosebrough NJ, Farr AL, Randall RJ (1951) Protein measurement with the Folin phenol reagant. J Biol Chem 193:265-275

Maier MS, Roccatagliata AJ, Kuriss A, Chludil H, Seldes AM, Pujol CA, Damonte EB (2001) Two new cytotoxic and virucidal trisulfated triterpene glycosides from the Antarctic sea cucumber Staurocucumis liouvillei. J Nat Prod 64: 732-736

Matutte B, Storey KB, Knoop FC, Conlon JM (2000) Induction of synthesis of an antimicrobial peptides in the skin of the freeze-tolerant frog, Rana sylvatica, in response to environmental stimuli. FEBS Lett 483:135-138

McLaren C, Ellis MN, Hunter GA (1983) A colorimetric assay for the measurement of the sensitivity of Herpes simplex viruses to antiviral agents. Antivir Res 3:223-234

Mitta G, Vandenbulcke F, Roch P (2000) Original involvement of antimicrobial peptides in mussel innate immunity. FEBS Lett 486:185-190

Nakamura T, Furunaka H, Miyata T, Tokunaga T and 5 others (1988) Tachyplesin, a class of antimicrobial peptide from the hemocytes of the horseshoe crab (Tachypleus tridentatus). J Biol Chem 263:16709-16713

Nousiainen M, Rafn K, Skou L, Roepstorff P, Andersen SO (1998) Characterization of exoskeletal proteins from the American lobster, Homarus americanus. Comp Biochem Physiol 119:189-199

Pan J, Kurosky A, Xu B, Choppa A, Coppenhave D, Singh I, Baron S (2000) Broad antiviral activity in tissues of crustaceans. Antivir Res 48:39-47

Prescott B, Li CP, Caldes G, Martino EC (1966) Chemical studies of paolin II, an antiviral substance from oysters. Proc Soc Exp Biol Med 123:460-464

Reed LJ, Muench HA (1938) A simple method of estimating fifty percent endpoints. Am J Hyg 27:493-497

Relf JM, Chisholm JR, Kemp GD, Smith VJ (1999) Purification and characterization of a cysteine-rich $11,5 \mathrm{kDa}$ antibacterial protein from the granular haemocytes of the shore 
crab, Carcinus maenas. Eur J Biochem 264:350-357

Renault T, Le Deuff RM, Cochennec N, Maffart P (1994a) Herpes-viruses associated with mortalities among Pacific oyster, Crassostrea gigas, in France: Comparative study. Revue Méd Vét 145:735-742

Renault T, Cochennec N, Le Deuff RM, Chollet B (1994b) Herpes-like virus infecting Japanese oyster (Crassostrea gigas) spat. Bull Eur Assoc Fish Pathol 14:64-66

Renault T, Le Deuff RM, Chollet B, Cochennec N, Gérard A (2000) Concomitant Herpes-like virus infection in hatchery-reared larvae and nursery-cultured spat Crassostrea gigas and Ostrea edulis. Dis Aquat Org 42:173-183

Ringwood A, Hoguet J, Keppler C (2002) Seasonal variation in lysosomal destabilization in oyster, Crassostrea virginica. Mar Environ Res 54:793-797

Roch P, Hubert F, Van Der Knaap W, Noël T (1996) Present

Editorial responsibility: Albert Sparks,

Seattle, Washington, USA knowledge on the molecular basis of cytotoxicity, antibacterial activity and stress response in marine bivalves. Ital J Zool 63:311-316

Shapiro HC (1975) Immunity in decapod crustaceans. Am Zool 15:13-19

Tamamura H, Kuroda M, Masuda M, Otaka A and 10 others (1993) A comparative study of the solution stuctures of tachyplesin I and a novel anti-HIV synthetic peptide, T22 ([Try 5,12, Lys 7]-polyphemusin II), determined by nuclear magnetic resonance. Biochim Biophys Acta 1163:209-216

Yasin B, Pang M, Turner JS, Cho Y, Dinh NN, Waring AJ, Lehrer RI, Wagar EA (2000) Evaluation of the inactivation of infectious herpes simplex virus by host-defense peptides. Eur J Clin Microbiol Infect Dis 19:187-194

Zasloff M (2002) Antimicrobial peptides of multicellular organisms. Nature 415:389-395

Submitted: January 28, 2005; Accepted: July 29, 2005

Proofs received from author(s): October 31, 2005 